\title{
Transitional cell carcinoma of the corpus uteri
}

INSERM

\section{Source}

INSERM. (1999). Orphanet: an online rare disease and orphan drug data base.

Transitional cell carcinoma of the corpus uteri. ORPHA:213746

A rare uterine cancer characterized by a usually intracavitary, friable, relatively wellcircumscribed tumor located in the corpus uteri, with possible infiltration of the myometrium, composed, microscopically, of cells resembling urothelial transition cells, with a papillary or polypoid growth pattern, typically admixed with another type of carcinoma (frequently endometrial adenocarcinoma), generally manifesting with postmenopausal vaginal bleeding. 